\title{
ISOLATION OF LEPTOSPIRA SANTAROSAI, SEROVAR GUARICURA FROM BUFFALOES (BUBALUS BUBALIS) IN VALE DO RIBEIRA, SÃO PAULO, BRAZIL
}

\author{
Silvio A.Vasconcellos ${ }^{1 *}$; João C.F. Oliveira ${ }^{1}$; Zenáide M. Morais ${ }^{1}$; Pietro S. Baruselli ${ }^{1}$; Renato Amaral ${ }^{1}$; \\ Sônia R. Pinheiro' ${ }^{1}$ Fernando Ferreira $^{1}$; José S. Ferreira- Neto ${ }^{1}$; Arno Schönberg ${ }^{2}$; Rudy A. Hartskeerl ${ }^{3}$
}

${ }^{1}$ Faculdade de Medicina Veterinária e Zootecnia, Universidade de São Paulo, São Paulo, SP, Brasil. ${ }^{2}$ Federal Institute for Health Protection of Consumers and Veterinary Medicine, Berlin, Germany (FAO/WHO Collaborating Centre for Research and Training in Food Hygiene and Zoonoses). ${ }^{3}$ KIT-Royal Tropical Institute, KIT-Biomedical Research (WHO/FAO/OIE Leptospirosis Reference Centre, Amsterdam, The Netherlands)

Submitted: May 24, 2001; Returned to authors for correction: July 24, 2001; Approved: September 03, 2001

\begin{abstract}
In April 1998 urine samples from adult female buffaloes were collected in a farm located in Registro, Vale do Ribeira, São Paulo State, Brazil. The urine samples obtained after furosemide injection were immediately transported to the laboratory in liquid modified EMJH medium and seeded, by the serial dilution technique, into Fletcher's or modified EMJH- $0.2 \%$ agar, both of them with 5 -fluorouracil $100 \mathrm{mg} / \mathrm{mL}$. The intraperitoneoum inoculation of $0.5 \mathrm{~mL}$ was also performed with each urine sample in young, adult hamsters (Mesocricetus auratus). All samples seeded directly in culture medium were contaminated. The hamsters did not show any sign of disease and were killed at the $21^{\text {st }}$ post inoculation day. At this time kidney cultures of these animals were performed and from one of them, one leptospira strain (M04-98) was isolated, identified as belonging to serogroup Sejroe by Microscopic Agglutination Test (MAT) with a panel of 36 rabbit sera against serovars representative for the pathogenic serogroups. Subsequently, MAT was carried out with antisera against the 19 reference strains of serogroup Sejroe, revealing a close relationship with serovar guaricura. Afterwards the MAT was done with a panel of 18 monoclonal antibodies representative for serovars of serogroup Sejroe. The histogram closely resembled that of serovar guaricura. So Cross Agglutination Absorption Test (CAAT) was carried out with the buffalo isolate and serovar guaricura, supporting the relationship between the buffalo isolate and serovar guaricura.
\end{abstract}

Key words: Leptospirosis, serogroup Sejroe, serovar guaricura, buffalo.

\section{INTRODUCTION}

In several regions of the world such as South America, Africa and Asia, buffaloes are important sources of proteins for human consumption. In Brazil the buffalo population of 2.5 million animals increases in an annual rate of $12 \%$, mainly in damp areas not proper for cattle exploitation (3).

Leptospirosis is one of the infectious diseases that in buffaloes cause symptoms like fever, jaundice, icterus, drop in milk production, abortion and repeated breeding $(1,11,20)$.
In spite of the availability of several serological surveys of leptospirosis in buffaloes in different countries of the world, very few investigations included isolation and typing of leptospires in these animals. These informations are necessary for the development of control measures such as vaccination.

Until now the leptospiral strains isolated from buffaloes are, serogroup Andamana in India (20); not typed spirochaet in Pakistan (1) and L. borgpetersenii, serogroup Sejroe, maybe a new serovar in Italy (18).

\footnotetext{
* Corresponding author. Mailing address: Universidade de São Paulo, Faculdade de Medicina Veterinária e Zootecnia, Departamento de Medicina Veterinária Preventiva e Saúde Animal, Av. Prof. Dr. Orlando Marques Paiva, 87. 05508-000. São Paulo, SP, Brasil, Fax: (+5511) 3091-7928. E-mail: savasco@usp.br
} 
The microscopic agglutination test (MAT) performed in buffaloes in Brazil presented positive results for different serovars, mainly to wolffi, hardjo, pomona, icterohaemorrhagiae and grippotyphosa $(6,7,8,9,12,13,14,15,21)$, but none of these results was confirmed by isolation and typing of leptospires.

This paper is the presentation of the first isolation and typing of leptospires isolated from buffaloes in Brazil

\section{MATERIALS AND METHODS}

In April 1998, urine samples were collected from 11 adult female buffaloes from a herd which had presented high MAT titres for leptospirosis mainly to serovars hardjo and wolffi. This farm is located in Registro, Vale do Ribeira, São Paulo, Brazil. Urine samples were obtained after furosemide injection $(0.8 \mathrm{mg} / \mathrm{kg}$, iv) and immediately transported to the laboratory in liquid modified EMJH medium, (2) and seeded, using the serial dilution technique, two tubes for each dilution, into Fletcher's or modified EMJH-0.2\% agar (2), both of them with 5-Fluorouracil $100 \mathrm{mg} / \mathrm{mL}$. The urine culture tubes were incubated at 28 to $30^{\circ}$ $\mathrm{C}$ and examined under darkfield microscopy during six weeks. Intraperitoneal inoculation of $0.5 \mathrm{~mL}$ of each urine sample in young/adult ( 80 to $120 \mathrm{~g}$ body weight) hamsters (Mesocricetus auratus) was also performed.

Rabbit antiserum against the isolated strain was produced in the Faculty of Veterinary Medicine University of São Paulo, according to Santa Rosa (16).

The isolated strain was identified and serotyped in WHO/ FAO/OIE Leptospirosis Reference Centre, Amsterdam, The Netherlands. The microscopic agglutination test (MAT) (4) was performed, with a panel of 36 rabbit sera against serovars representative of the pathogenic serogroups. After serogroup identification, the test was repeated with antisera against the serogroup reference strains, monoclonal antibodies typing (19) and cross agglutination absorption test (CAAT) (4).

\section{RESULTS}

All samples seeded directly in culture medium presented contamination and were discarded. Hamsters did not show any sign of disease and were killed at the $21^{\text {st }}$ post-inoculation day; kidney cultures of these animals were performed, and a leptospira strain, named as M-04-98, was isolated from one of them.

The MAT with a panel of 36 rabbit sera against serovars representative of the pathogenic serogroups showed that the isolated strain belonged to the Sejroe serogroup. Subsequently, MAT was done with antisera against the 19 reference strains of Sejroe serogroup revealing close relationship with serovar guaricura. Afterwards the MAT was done with a panel of 18 monoclonal antibodies representative for Sejroe serovars and the histogram closely resembled that of serovar guaricura (Fig. 1). CAAT, done with the buffalo isolate and the serovar
Table 1. Titres obtained in the Cross Agglutination Absorption Test according to the antigens and antisera.

\begin{tabular}{lccc}
\hline \multirow{2}{*}{ Antiserum } & Absorbent & \multicolumn{2}{c}{ Antigen } \\
\cline { 3 - 4 } & Antigen & guaricura & M-04-98 \\
& & Bov G & \\
guaricura Bov G & none & 5120 & 2560 \\
guaricura Bov G & M-04-98 & 80 & --- \\
M-04-98 & none & 20480 & 20480 \\
\hline
\end{tabular}

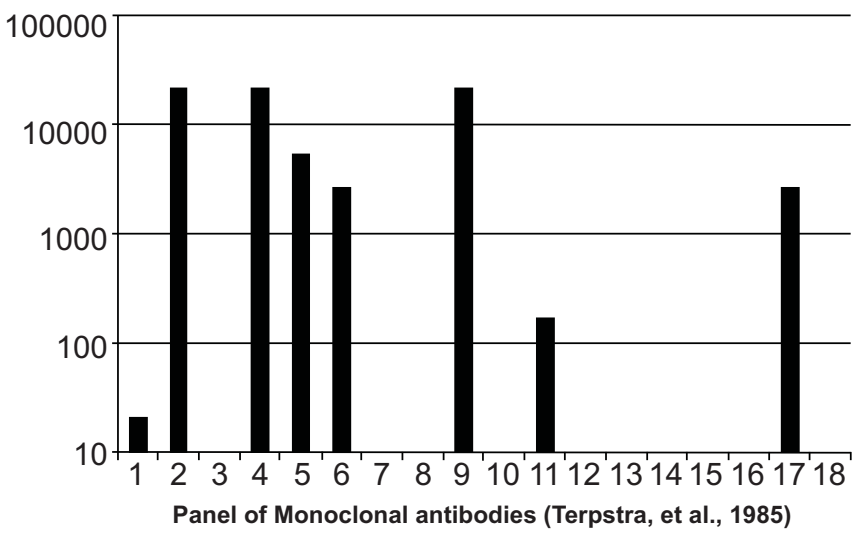

Figure 1. Histogram of reaction patterns of strain M-04-98 with monoclonal antibodies developed at the Royal Tropical Institute, Amsterdan, The Netherlands.

guaricura, supported the relationship between them (less than $10 \%$ remaining titre) (Table 1).

\section{DISCUSSION}

The leptospires serovars already isolated from buffaloes are serogroup Andamana, in one case of jaundice in India (20), a not typed strain, from buffalo milk, in a case of flaccid mastitis in Pakistan (1), and maybe a new serovar that belongs to serogroup Sejroe, isolated from the kidneys of healthy buffaloes in Italy (18).

In the present work, Leptospira santarosai, serovar guaricura, serogroup Sejroe, strain M04-98 was isolated from the urine of a healthy female buffalo in a herd located in Vale do Ribeira, São Paulo, Brazil. This serovar, strain Bov-G, was first isolated in Brazil by Santa Rosa et al. (17), from kidney samples of cattle collected in the slaughterhouse. At that time, the strains was classified in the Hebdomadis serogroup, but nowadays it belongs to the serogroup Sejroe (10). This was the first description of a leptospira strain isolated from buffalo in Brazil, reinforcing the statement that buffaloes could be hosts of leptospires of the Sejroe serogroup (5). The failure of isolation from direct culture 
stressed the importance of the use of laboratory animals in leptospirosis research. Although presenting no pathogenicity for hamsters, the strain reached the kidney tissue of these animals, as demonstrated by the blind passage.

The inclusion of serovar guaricura in the serological examination of buffaloes in Brazil will improve the interpretation of results of typing of leptospira of Sejroe serogroup.

\section{AKNOWLEDGMENTS}

This work was supported by grant $\mathrm{n}^{\circ}$ FAPESP: 97/09275-8/ CNPq 524437/96-3(NV).

\section{RESUMO \\ Isolamento de Leptospira santarosai, sorovar guaricura de búfalos (Bubalus bubalis) do Vale do Ribeira, São Paulo, Brasil}

Em Abril de 1998 foram colhidas amostras de urina de búfalas fêmeas adultas em uma Fazenda localizada em Registro, Vale do Ribeira, São Paulo, Brasil. Estas amostras foram obtidas após a injeção de furosemida $(0,8 \mathrm{mg} / \mathrm{kg}$, iv), transportadas para o Laboratório em meio de EMJH modificado e semeadas pela técnica das diluições seriadas em meios de Fletcher ou EMJH modificado com $0,2 \%$ de agar, ambos acrescidos de 5 -fluorouracil $100 \mathrm{mg} / \mathrm{mL}$. Também foi efetuada a inoculação, em hamsters (M.auratus), 0,5 mL da amostra, via intraperitonial. Todos os cultivos de urina apresentaram contaminação e foram descartados. Os hamsters não apresentaram sinais de doença e foram sacrificados no $21^{\circ}$ dia pós-inoculação; nesta ocasião foram efetuados cultivos do tecido renal destes animais, dos quais foi isolada uma estirpe de leptospira (M04-98). A identificação deste isolado foi iniciada com um painel de 36 antisoros contra amostras patogênicas e o mesmo foi identificado como pertencente ao sorogrupo Sejroe. Subseqüentemente com painel de anticorpos monoclonais e teste de absorção cruzada de aglutininas a identidade do isolado foi confirmada como L. santarosai, sorogrupo Sejroe, sorovar guaricura. Este foi o primeiro isolamento de leptospira de búfalos efetuado no Brasil.

Palavras-chave: Leptospirose, sorogrupo Sejroe, sorovar guaricura, búfalos.

\section{REFERENCES}

1. Ahmed, R. Leptospiral infection in lactating buffaloes. Pak. Vet. J., 10: $98,1990$.

2. Alves, C.J.; Vasconcellos, S.A.; Camargo, C.R.A.; Morais, Z.M. Influência de fatores ambientais sobre a proporção de caprinos sororeatores para a leptospirose em cinco centros de criação do Estado da Paraíba, Brasil. Arq. Inst. biol., (S. Paulo), 63: 11-18, 1996.
3. Baruselli, P.S.; Oliveira, J.F.S.; Mendes, M.L.M.; Jorge, A.M.; Fujii, T.; Palazzo, J.P.C. Diagnóstico da bubalinocultura do Vale do Ribeira, Campinas, SP, 1993, 16 p. (Doc. Téc. CATI nº94).

4. Faine, S. Guidelines for the control of leptospirosis. Geneva, World Health Organization, 1982, 171p. (Whо offset publications, 67).

5. Faine, S.; Adler, B.; Bolin, C.; Perolat, P. Leptospira and Leptospirosis. MediSci, Melbourne, 1999, $2^{\text {nd }} . e d .$, 272p.

6. Favero, A.C.M.; Vasconcellos, S.A.; Morais, Z.M.; Ferreira Neto, J.S.; Pinheiro, S.R. Estudo retrospectivo dos exames de leptospirose realizados no Laboratório de Zoonoses Bacterianas da Faculdade de Medicina Veterinária e Zootecnia da Universidade de São Paulo, no período de 1984 a 199. XX Congresso Brasileiro de Microbiologia, Salvador, 1999, p.137.

7. Fujii, T.U. Frequência de ocorrência de anticorpos contra Neospora caninum (Dubey, Carpenter, Speer, Topper \& Uggla 1988), em búfalas (Bubalus bubalis) no Vale do Ribeira, Estado de São Paulo/. São Paulo, 2000, 79p. (M Sc Thesis. Faculdade de Medicina Veterinária e Zootecnia. USP).

8. Giorgi, W.; Teruya, J.; Silva, A.S.; Genovez, M.E. Leptospirose: resultados das soroaglutinações realizadas no Instituto Biológico de São Paulo durante os anos de 1974/1980. Biológico, (S. Paulo), 47: 299-309, 1981.

9. Girio, R.J.S.; Yanaguita, R.M.; Mathias, L.A. Comparative study of four saprophytic Leptospira strains as screening antigens in the serodiagnosis of leptospirosis in water buffaloes (Bubalus bubalis) Int. J. Zoonoses. 12: 61-66, 1985.

10. Instituto Pasteur Leptospira santarosai by Serogroup. França, Instituto Pasteur, 1998. (Eletronic Publication). (On line, 30 de agosto de 1998, http://www.pasteur.fr/Bio/Leptospira/ santarosai.html).

11. Khan, M.A.; Khan, M.S. Seroprevalence od Leptospira interrogans in the aborting dairy buffaloes. In Proceedings of II World Buffalo Congress, India, 1988, v.1, II, p.57-60.

12. Krahl, M.A.; Fortes, M.; Wunder, E.; Montana, M. Estudo sorológico visando a presença de anticorpos para Leptospira spp. em bubalinos do Rio Grande do Sul. In: XX Congresso Brasileiro de Microbiologia,, Salvador, 1999, p.142.

13. Langoni, H.; Del Fava, C.; Cabral, K.G.; Da Silva, A.V.; Chagas, S.A.P. Aglutininas antileptospíricas em búfalos do Vale do Ribeira, Estado de São Paulo. Ciência Rural, Santa Maria, 29: 305-307, 1999.

14. Pereira, H.S.; Blume, H.; Solano, R.F.; Nascimento, C. Incidência da leptospirose em búfalas no Maranhão. Rev. Bras. Reprod. Anim., 23: 3: 418-420, 1999.

15. Sandoval, L.A.; Arruda, N.M.; Teruya, J.M.; Giorgi, W.; Amaral, L.B.S.; Mazanti, M.T. Estudo de búfalos: prevalência de brucelos e leptospirose no Estado de São Paulo, Brasil. Biológico (S Paulo), 45: 209-212, 1979.

16. Santa Rosa, C.A. Diagnóstico laboratorial das leptospiroses. Rev. Microbiol., 1: 97-109, 1970.

17. Santa Rosa, C.A.; Sulzer, C.R.; Pestana de Castro, A.F.; Yanaguita, R.M.; Giorgi, W. Two new leptospiral serovars in the hebdomadis group isolated from cattle in Brasil. Int. J. Zoonoses., 7: 158-163, 1980.

18. Telò, P.; Autorino, G.; Amaddeo, D.; Tagliabue, S.; Finazzi, G.; Pacciarini, M.L. Genetic characterization of a new leptospira belonging to serogroup Sejroe isolated from buffalo in Central Italy. In: II international Leptospirosis Society Congress, Marysville, Australia, 1999, p.77.

19. Terpstra, W.J.; Korver, H.; Van Leewen, J.; Klatser, P.K.; Kolk, A.H.J. The classification of Sejroe group serovars of Leptospira interrogans with monoclonal antibodies. Zbl. Bakt. Hyg. A., 259: 498-506, 1985.

20. Upadhye, A.S.; Rajasekhar, M.; Ahmed, S.N.; Krishnappa, G. Isolation of Leptospira andaman from an active case of jaundice in a Buffalo. Indian vet. J., 60: 319-320, 1983.

21. Yasuda, P.H.; Samara, S.I.; Pinto, A.A. Aglutininas antileptospiras em búfalas no Estado de São Paulo, Brasil. In. VII Encontro de Pesquisas Veterinárias, Faculdade de Ciências. Agrárias e Veterinárias, Jaboticabal, 1982. p.105-106. 